\title{
KOMUNIKASI KEBIJAKAN PEMERINTAH MELAHIRKAN PELANGGARAN DALAM KEBAKARAN HUTAN DAN LAHAN
}

\author{
Irsadi Aristora \\ Program Studi Ilmu Komunikasi, Universitas Teuku Umar \\ Email: irsadiaristora@utu.ac.id
}

\begin{abstract}
A result of the magnitude of the impact of the effects damage to of smoke and nature due to impact of about fire that, Part of institutions in this country wash hands and throw the ball the heat to other institutions. Governmental Organization (NGO), both nationally and abroad accuse the fault is on the part of country that have issued permits in areas that should not be issued. While the institution of ministry mutual self-defense and ministries blame the institution other as an object of the problems responsible for the incident. James A.F. Stoner, and Charles Wankel (1989) argues that the communication is one way humans relate that involves understanding or intention, on the condition that they have to agree with the definition of terms used by something symbolic like signs, letters, numbers, and words that symbolize or resemble ideas that can convey meaning. Then, according to Littlejohn importance of communication is: something everyday casual look, turned into a big puzzle for someone so he wanted to find meaning / understanding hidden inside something that. So, the communication aims to search for meaning. Licensing Service Agency integrated (BP2T) whose job it authorizes the issuance of licenses on the proposer without referring to the legislation in force in the country. Government policy Communication more clearly visible so not running properly In legal terms "stric liability" can be accounted deed to anyone, who has a real basis on legal facts giving Permissions area has been declared a protected area that should be protected by law and regulations.
\end{abstract}

Keywords: Communication Policy, Land and Forest Fire.

\section{PENDAHULUAN}

Hutan Aceh dalam sesuai dengan Arahan Fungsi Hutan Surat Keputusan Gubernur Aceh Nomor 19, Tahun 1999 memiliki luasan sebesar 3,335,613 Ha. Dari arahan fungsi tersebut ruang pemanfaatan hutan secara fungsi nya ditata sebagai Hutan Lindung, Kawasan Konservasi, Hutan Produksi dan Hutan Produksi Tetap. Sementara Penujukan Kawasan Hutan dan Perairan dalam Keputusan Menteri Kehutanan Nomor 170/KptsII/2000, Tahun 1999, menyatakan kalau Aceh memiliki Luas Total Kawasan sebanyak 3,549,813 Ha. Kondisi hutan Aceh yang semakin degradasi akibat praktek pembalakan liar, perambahan hutan dan penguasaahan hutan untuk pertambangan dan perkebunan sawit telah mengacam paru-paru dunia yang selama ini menjadi harapan dunia.

Permasalahan Umum hutan dan lingkungan memiliki persamanaan dasar masalah yang timbul karena; 1) Dinamika pertumbuhan penduduk yang cepat dan penyebaran yang tidak proposional. 2) Pemanfaatan dan pengelolaan sumber daya alam yang kurang bijaksana dan lestari. 3) Kurang terkendalian nya pemanfaatan ilmu pengetahuan dan teknologi maju. 4) Dampak negative dari perkembangan pembangunan dan industry. 5) Benturan Tata Ruang (Dr. Siswanto Sunarso, S.H, M.H. 2005, 5)

Hutan adalah suatu kesatuan ekosistem berupa hamparan lahan berisi sumber daya alam hayati yang di dominasi pepohonan dalam persekutuan alam lingkungan nya, yang satu dengan lain nya tidak dapat dipisahkan. Hutan sebagai bahagian dari lingkungan hidup merupakan sumber daya alam hayati Indonesia dan ekosistem nya yang mempunyai 
kedudukan serta peranan penting bagi kehidupan adalah karunia Tuhan Yang Maha Esa, oleh karena itu perlu di kelola dengan dimanfaatkan dengan lestari, selaras, dan seimbang bagi kesejahteraan masyarakat Indonesia pada khusus nya dan umat manusia pada umum nya, baik kini maupun masa depan.

Kebakaran hutan dan lahan di Sumatera dan Kalimantan telah menjadi bencana nasional yang terus berulang setiap Tahun. Seakan-akan menujukan ketidakberdayaan negara dalam menyelesaikan permasalahan ini. Semakin banyak korban jiwa, harta dan benda terus berjatuhan serta menghasilkan kerugian negara terhadap korban asap maupun yang lahannya terbakar. Pesimisme rakyat terhadap pemimpin menjadi berkurang terhadap kasus yang terus berulang karena tidak ada pelaku yang berhasil dijatuhi hukuman yang sebanding dengan apa yang diakibatkan.

Segala daya dan upaya telah dikerahkan negara dalam memadamkan api dikawasan gambut yang kini dikuasai oleh pengusaha perkebunan. Pasukan TNI, POLRI, Relawan Lingkungan, Masyarakat dan Tim Pemadam dari Pemerintah setempat, Magala Agni serta negara-negara tetangga ikut membantu memadamkan api didaerah yang telah terbakar. Hingga saat tulisan ini ditulis belum menujukan perkembangan yang siqnifikan bila dibanding dengan biaya dan kerugian negara yang telah keluarkan untuk proses pemadaman. Perhatian dunia terhadap hutan tropis yang diharapkan dapat menjadi paruparu dunia malah sebaliknya menjadi penghasil dan pengekpor polusi karbon terbesar didunia.

Akibat besarnya dampak yang ditimbulkan dari pengaruh asap maupun kerusakan alam akibat kebakaran tersebut, sebagaian lembaga dinegara ini saling cuci tangan dan melempar bola panas kepada lembaga lainnya. Lembaga Swadaya Masyarakat (LSM) baik nasional dan luar negeri menuding kesalahan ada dipihak negara yang telah mengeluarkan izin pada kawasan yang seharusnya tidak dikeluarkan. Sementara lembaga kementarian saling melakukan pembelaan diri dan menyalahkan lembaga kementerian lainya sebagai objek permasalahan yang bertanggungjawab atas kejadian tersebut.

Ruang-ruang komunikasi lintas kementerian dan lembaga negara lainya membuat masyarakat bingung mana yang benar. Akses ketidak jelasan komunikasi ini menghasilkan ketidak percayaan rakyat terhadap kabinet negara yang dibangun Presiden. Kredibilitas dan akuntabilitas pemerintah diuji karena adanya kesalahan komunikasi dari lembaga-lembaga ini dalam menerbikan kebijakan dan terutama terhadap kebijakan penerbitan izin pemanfaatan lahan, hutan dan sumber daya alam lainnya. Komunikasi lintas sektor ini menujukan sikap ego lembaga negara terhadap institusinya saja.

\section{KERANGKA TEORI}

Dilihat dari karya-karya dibuat oleh Hans Kelsen, pemikiran yang dikemukakan meliputi tiga masalah utama yaitu tentang teori hukum, Negara dan hukum international. Ketiga masalah tersebut tidak dapat dipisahkan satu dengan lainnya karena saling terkait dan dikembangkan secara konsisten berdasarkan logika hukum secara formal.

Teori umum yang dalam buku Prof. Dr. Jimly Asshiddiqie., SH dan M. Ali Safa'at,. SH,. MH. $(2006,8)$ dikembangkan oleh Hans Kelsen meliputi dua aspek penting yaitu Aspek Statis (nomostatics) melihat perbuatan yang diatur oleh hukum, kemudian Aspek Dinamis (nomodinamic) melihat hukum yang mengatur sesuatu. Friedmann, mengungkap dasar-dasar esensial dari pemikiran Kelsen sebagai berikut;

a. Tujuan teori hukum, seperti setiap ilmu pengetahuan, adalah untuk mengurangi kekacauan dan kemajemukan menjadi kesatuan.

b. Teori hukum adalah ilmu pengetahuan mengenai hukum yang berlaku, bukan mengenai hukum yang seharusnya.

c. Hukum adalah ilmu pengetahuan normatif, nukan ilmu alam. 
d. Teori hukum sebagai teori tentang norma-norma, tidak ada hubungannya dengan daya kerja norma-norma hukum.

e. Teori hukum adalah formal, suatu teori tentang cara menata, mengubah isi dengan cara yang khusus. Hubungan Antara teori hukum dan system yang khas dari hukum positif ialah hubungan apa yang mungkin dengan hukum yang nyata.

Pendekatan yang dilakukan oleh Kelsen disebut The Pure Theory of Law, mendapatkan tempat tersendiri karena berbeda dengan dua kutub pendekatan yang berbeda Antara mazhab hukum alam dengan Positivisme empiris. Beberapa ahli menyebutkan pemikiran Kelsen sebagai "Jalan Tengah "dari dua aliran hukum yang telah ada sebelumnya.

Hans Kelsen memiliki kesamaan dalam ruang teori Positivisme empiris dalam suatu bentuk pemerintahan dengan Montesquieu, suatu sistem hukum harus bisa ditemukan lebih dari pada bisa ditemukan. Karena sejatinya sistem hukum merupakan hasil dari kompleksitas berbagai faktor empiris dalam kehidupan manusia. Dihasilkan dalam karya Charles-Lois de Secondat de la Bre'de et de Montesquieu yang berjudul L'Esprit des Lois (Roh Hukum).

Hukum bukan merupakan dari manifestasi dari otoritas super human, tetapi merupakan teknik social yang spesifik berdasarkan pengalaman manusia. The pure theory of law menolak menjadi kajian metafisis tentang hukum. Teori ini mencari dasar-dasar hukum sebagai landasan validitas, tidak pada prinsip-prinsip meta-yuridis, tetapi melalui suatu hipotesis yuridis, yaitu suatu norma-norma dasar, yang dibangun dengan analisis logis berdasarkan cara berfikir yuristik actual.

The pure theory of law, berbeda dengan analytical jurisprudence yang dalam hal ini the pure theory of law lebih konsisten mengunakan metodenya terkait dengan masalah konsep-konsep dasar, hak hukum, norma hukum, kewajiban hukum, dan hubungan antara Negara dan hukum.

Dalam tesis Montesquieu, faktor iklim dan lingkungan tidak saja berpengaruh pada watak manusia / masyarakat, tetapi juga pada sifat dan bentuk kegiatan, cara hidup bermasyarakat dan lembaga-lembaga sosial. Serentak dengan itu iklim juga mempengaruhi moral, ekonomi, agama dan bentuk pemerintahan. Karena adanya kekhasan iklim dan kondisi daratan, maka apa yang dikerjakan oleh seuatu masyarakat tidak perlu dilakukan oleh masyarakat lain. Implikasinya adalah, adanya relativism, termasuk dibidang moral.

Tidak ada penilaian moral yang benar-benar independen dan netral yang dapat dibuat dalam masyarakat dan budaya berbeda. Setiap penilaian moral berkembang diluar suatu masyarakat atau budaya, tidak bisa diterapkan begitu saja pada masyarakat tersebut. Demikian juga suatu tatanan hukum diluar, tidak bisa ditransfer dan dipakai begitu saja untuk suatu masyarakat yang ditulis dalam buku Bernard L. Tanya, dkk, Teori Hukum Strategi Tertib Manusia Lintas Ruang dan Generasi. (2010, 82 - 83).

Dari rangkaian penjelasan Montesquieu, beberapa kelemahan penegakan hukum khususnya terhadap tindak pidana yang mengarah kepada korupsi belum bisa dijalankan secara langsung terhadap masyarakat dan budaya di Indonesia khususnya di Provinsi Aceh. Teori yang bersifat sosiologis ini juga berbicara tentang hukum alam, merupakan hukum kodrat yang utama yang dijelaskan Montesquieu.

Perlu diingat dalam konsep Montesquiue, hukum yang memunculkan gagasan Sang Pencipta pada pikiran masnusia serta membuat manusia codong kepada -Nya, adalah hukum yang paling penting, kendati bukan yang utama dalam hukum tatanan alam. Inilah yang diyakini oleh semua manusia dalam melihat dampak dan kodrat dari teori yang disampaikan oleh Montesquieu, bila kerusakan hutan dari prektek Tindak Pidana yang dihasilkan dari kegiatan disektor kehutanan terjadi, maka hukum alam dari Sang Pencipta alam semesta ini akan terjadi bencana. 
Secara moral, kebiasaan korupsi yang terbungkus dalam praktek suap, sogok dan transaksi kebijakan dari penguasa dan pemerintah dipengaruhi iklim dan daratan atau kepulauan sudah dianggap hal biasa yang lama kelamaan menjadi budaya masyarakat. Walau secara hukum yang dibentuk merupakan pelanggaran, akan tetapi secara sosioligis dan moral tidak ditakuti sebagai pelanggaran terhadap tatanan hukum dan aturan.

\section{KERANGKA KONSEP}

Dalam melihat konsep penelitian ini, diperlukan sebuah payung hukum yang jelas terhadap tindak pidana yang dilakukan dalam kejahatan disektor kehutanan merupakan tindakan korupsi berdasarkan peraturan dan perundangan yang ada di Indonesia dan kekhususan Aceh dengan UU Nomor 11 Tahun 2006 tentang Pemerintahan Aceh.

Melihat dari konsep yang dijelaskan oleh Montesquieu dalam teori yang lain tentang hukum. Pertama, hukum alam yang jelas tidak dapat diubah dan dipertentangkan. Kedua, Hukum Agama yang berasal dari Tuhan. Ketiga, Hukum Moral dari ahli filsafat dimana hukum ini dapat dibuat dan diubah. Keempat, hukum politik dan sipil. Hukum (hak-hak) politik berkaitan dengan struktur konstitusional, hubungan dari yang memerintah dengan yang diperintah, dan gabungan dari kekuatan, keunggulan dan kekuasaan. Sedangkan Hukum (hak-hak) sipil merupakan hubungan keinganan-keingan individu.

Dampak korupsi terhadap tindak pidana disektor kehutanan dijabarkan dari konsep diatas, menujukan bahwa ada hubungan antara teori hukum dengan permasalahan penelitian ini. Hal yang terlihat adalah adanya konsep hukum yang berlaku terhadap dampak dari kriminalisasi pada sektor yang dimaksud. Hutan dalam satu kesatuan ekosistem dan mata rantai dalam kehidupan planet bumi ini saling membutuhkan dalam sebuah pemahaman bagi keberlangsungan hidup semua makhluk khususnya manusia.

Korupsi yang ditargetkan dalam penelitian ini merupakan skema hukum yang sedang bombastis diisu media dan perbicangan masyarakat Indonesia. Kemasan korupsi ini menjadi target dalam penelitian dalam pemahaman isi tulisan tesis ini agar semua bisa disepakati bahwa pelanggaran yang dihasilkan dari penelitian ini adalah tindak pidana korupsi (Tipikor).

\section{Komunikasi Kebijakan Pemerintah}

Melihat latar belakang masalah dari pendahuluan diatas, maka kita perlu menjelaskan definisi komunikasi pada perkembangan saat ini yang telah berbeda dengan definisi komunikasi pada masa lalu. Sejak lama definisi komunikasi dititikberatkan pada proses menyampaikan sesuatu kepada orang lain seperti peyakinan atau usaha untuk merubah tingkah laku orang lain. Namun Communication Theory Today (mulai 1995) memberikan definisi yang berbeda mengenai komunikasi (Zawani, 2014).

Pertama, memberi penekanan pada proses penyampaian berita berdasarkan teori Lasswell tentang komunikasi: "Who says what in which channel to whom with what effect" menyatakan bahwa obyek kajian komunikasi berupa:

1. Analisis sumber (komunikator)

2. Analisis isi (pesan)

3. Analisis media (saluran)

4. Analisis khalayak (komunikan)

5. Analisis efek (dampak). 
Kedua, memberi penekanan pada proses pertukaran nilai atau proses pertukaran pikiran. James A. F. Stoner \& Charles Wankel (1989) (dalam Zawani, 2014) menyatakan bahwa komunikasi ialah satu cara manusia berhubungan yang melibatkan pengertian atau maksud, dengan syarat mereka perlu setuju dengan definisi istilah-istilah yang digunakan berdasarkan sesuatu yang simbolik seperti isyarat, huruf, nomor, dan perkataan yang melambangkan atau menyerupai ide-ide yang dapat menyampaikan maksud. Kemudian menurut Littlejohn pentingnya suatu komunikasi adalah: sesuatu yang sehari-hari terlihat biasa, berubah menjadi teka-teki besar bagi seseorang begitu ia bermaksud mencari makna/pengertian yang tersembunyi di dalam sesuatu itu. Jadi, komunikasi bertujuan untuk mencari makna.

Bila dilihat hubungan antara komunikasi dengan sistem pemerintahan yang ada dinegara ini. Maka dalam sistem pemerintahan, memang memungkinkan bagi hadirnya sistem-sistem lainnya yang satu dengan lainya saling berhubungan dan mendukung. Dalam hal ini terbentuk hubungan pemerintahan dan komunikasi antara pemerintahan dengan yang diperintah dan yang diperintah dengan yang menjalankan kebijakan. Inilah yang kemudian disebut dengan Komunikasi Pemerintahan yang baik dan akuntabilitas.

Komunikasi pemerintahan kemudian membentuk hibrida-hibrida baru antara lain seperti, komunikas antar manusia, komunikasi publik, komunikasi politik, komunikasi organisasional, yang kemudian menjadi konstruksi komunikasi pemerintahan. Khusus bagi ilmu pemerintahan, komunikasi politik digunakan sebagai alat yang digunakan untuk menjalankan fungsi-fungsi setiap sistem politik. Alat yang dapat digunakan oleh aktoraktor politik dalam berkomunikasi dan meyakinkan publik adalah simbol-simbol, bahasa, dan opini publik dengan kepentingan sebagai muatannya (pesan/messages), melalui advokasi, propaganda, iklan provokasi, dan retorika.

Untuk menyukseskan kerjasama sehingga dapat mencapai hasil yang besar dan menyeluruh bagi keseluruhan masyarakat, bangsa dan negara Indonesia, tentu system politik memiliki fungsi yang perlu dilaksanakan, meskipun fungsi ini tidak memiliki "pengaruh secara langsung dalam pembuatan dan pelaksanaan kebijaksanaan pemerintah (public policy) tetapi memiliki peranan yang sangat penting dalam menentukan cara bekerjanya system politik" (Gabriel A. Almond). Fungsi sistem politik ini mempengaruhi lingkungan fisik, social dan ekonomi domestik, kelompok kepentingan, partai politik, badan lebislatif, eksekutif, birokrasi, dan badan-badan peradilan. Dalam rilis SATGAS REDD tgl 13 April 2012, terdapat catatan penting terkait pelanggaran yang terjadi, hukum a harus ditegakkan. Dari hasil temuan SATGAS ada 3 peraturan perundangan yang dilanggar yaitu:

1) UU No. 18 Tahun 2004 Tentang Perkebunan.

2) UU No. 32 Tahun 2009 Tentang Perlindungan dan Pengelolaan Lingkungan Hidup.

3) UU No. 26 Tahun 2007 Tentang Penataan Ruang Junto Kepres No. 32 Tahun 1990 Tentang Pengelolaan Kawasan Lindung.

Pernyataan MENHUT yang menyatakan "Kementerian Kehutanan baru akan bertanggung jawab apabila kawasan Rawa Tripa masuk dalam kawasan hutan lindung atau kawasan ekosistem taman nasional. Sedangkan Rawa Tripa, merupakan areal penggunaan lain dan perizinan pengelolaan kawasan tersebut telah berubah menjadi lahan perkebunan di mana izin hak guna usaha (HGU)-nya diberikan oleh pemerintah daerah (sumber Harian Serambi Indonesia - 7 Mei 2012)". 


\section{Hasil dan Pembahasan Analisis Pelanggaran Dalam Kebakaran Hutan dan Lahan}

\section{Melanggar Hak Azasi Manusia}

Kebakaran hutan dan lahan menghasilkan efek domino yang mensuplai asap kemana-mana telah mencabut hak-hak warga Negara secara brutal. Seakan tak pernah perduli soal manusia demi sebuah keuntungan pribadi belaka. Padahal jelas dalam UU Nomor 39 Tahun 1999 Tentang HAM, Pasal 9 ayat (3) Setiap orang berhak atas lingkungan hidup yang baik dan sehat. Saat ini terlihat jelas, Sudah berTahun -Tahun lamanya kabut asap dari aktivitas kebakaran hutan dan lahan di Sumatera dan Kalimantan tidak kunjung reda.

Bahkan kabut asap tebal masih menyelimuti Indonesia dan negara lain disekitar Indonesia berakibat jatuhnya korban jiwa yang berdampak terhadap kesehatan umat manusia di dunia. Jumlah titik api yang terpantau oleh satelite seperti yang dilaporkan kepada media memang fluktuatif setiap harinya namun asapnya seakan tak habis-habisnya. Beberapa maskapai penerbangan diberbagai bandara memutuskan membatalkan penerbangannya di Bandara Kualanamu Sumatera Utara. Faisal salah seorang petugas Bandara dari Angkasapura menjelasakan bahwa, "pembatalan penerbangan dikarenakan jarak pandang tidak mencapai $3-5 \mathrm{Km}$ sehingga dikhawatirkan berbahaya bagi penerbangan antar domestic seperti Kualanamu menuju Batam, Pekanbaru, Jakarta dan Singapura".

Hak Azasi Manusia dalam UU Nomor 39 Tahun 1999 Tentang HAM, menjelaskan bahwa Hak Asasi Manusia adalah seperangkat hak yang melekat pada hakikat dan keberadaan manusia sebagai makhlukTuhan Yang Maha Esa dan merupakan anugerah-Nya yang wajib dihormati, dijunjung tinggi dan dilindungi oleh negara, hukum, Pemerintah, dan setiap orang demi kehormatan serta perlindungan harkat dan martabat manusia. Dijelaskan dalam Pasal 9; (1) Setiap orang berhak untuk hidup, mempertahankan hidup dan meningkatkan taraf kehidupannya. (2) Setiap orang berhak hidup tenteram, aman, damai, bahagia, sejahtera lahir dan batin. (3) Setiap orang berhak atas lingkungan hidup yang baik dan sehat. Pasal 64, Setiap anak berhak untuk memperoleh perlindungan dari kegiatan eksploitasi ekonomi dan setiap pekerjaan yang membahayakan dirinya, sehingga dapat mengganggu pendidikan, kesehatan fisik, moral. kehidupan sosial, dan mental spiritualnya. Dalam kejadian ini, banyak hal hak-hak manusia yang tercabut secara tidak disengaja akibat ulah pembakaran lahan tersebut adalah;

a. Hilangnya udara yang bersih yang menjadi Hak utama bagi manusia.

b. Hak Pendidikan yang terganggu akibat asap yang menyelimuti sehingga mengkhawtirkan dapat menimbulkan penyakit bagi anak-anak sekolah.

c. Hak kebebasan menjalankan usaha.

\section{Melanggar Lingkungan Hidup}

Undang-Undang RI Nomor 32 Tahun 2009 tentang Perlindungan dan Pengelolaan Lingkungan Hidup (Lembaran Negara RI Tahun 2009 Nomor 140, secara jelas menegaskan perundangan di Indonesia secara tegas menjelaskan "Setiap Orang Wajib ", sehingga bila kita coba memaknai kalimat tersebut bahwa wajib bagi setiap orang atau manusia mematuhi segala aturan tersebut. Konsekwensi bila kita tidak mengindahkan aturan tersebut akan ada sangsi yang diberika kepada orang yang melanggar. Tujuan hukum untuk memberi efek jera kepada manusia atau orang yang melanggar kewajibannya tidak 
berjalan di Indonesia, justru hak-hak lingkungan hidup yang menjadi dasar dari manusia sendiri dilanggar demi kepentingan pribadi dan mengorbankan manusia lainya.

Pasal 6 Undang-Undang Nomor 23 Tahun 1997 tentang Pengelolaan Lingkungan Hidup, menyatakan:

a. Setiap orang berkewajiban memelihara kelestarian fungsi lingkungan hidup serta mencegah dan menanggulangi pencemaran dan perusakan.

b. Setiap orang yang melakukan usaha dan/atau kegiatan berkewajiban memberikan informasi yang benar dan akurat mengenai pengelolaan lingkungan hidup.

Melihat fenomena saat ini, miris kita melihat ketidak pedulian manusia pemilik perusahaan yang dengan sengaja ataupun tidak membakar lahannya. Dengan alasan demi penghematan biaya oprasional pembersihan lahan maupun akibat pemanasan dari global warming pengusaha tidak menghiraukan atau melaporkan kejadian kebakaran hutan dan lahan diwilayah mereka.

\section{Melanggar Tata Ruang}

Merujuk Undang-Undang Nomor 26 Tahun 2007 Tentang Penataan Ruang; Pasal 61 hurut (d), yang menyebutkan bahwa "Dalam pemanfaatan ruang, setiap orang wajib memperhatikan daya dukung dan daya tampung lingkungan", Pasal 69 ayat (1) Undangundang Nomor 26 Tahun 2007 Tentang Penataan Ruang "Setiap orang yang tidak menaati rencana tata ruang yang telah ditetapkan sebagaimana dimaksud dalam Pasal 61 huruf (a), yang mengakibatkan perubahan fungsi ruang, dipidana dengan pidana penjara paling lama 3 (tiga) Tahun dan denda paling banyak Rp. 500.000.000,00 (lima ratus juta rupiah). Disinilah tata komunikasi kebijakan pemerintah mulai terlihat aburadul dan tidak terkoordinasi dengan baik.

Lantas kepada siapa lagi kita harus menegakan supremasi hukum dinegara ini bila kita coba mengupas Pasal 73 ayat (1) Setiap pejabat pemerintah yang berwenang yang menerbitkan izin tidak sesuai dengan rencana tata ruang sebagaimana dimaksud dalam Pasal 37 ayat (7), dipidana dengan pidana penjara paling lama 5 (lima) Tahun dan denda paling banyak Rp. 500.000.000,00 (lima ratus juta rupiah). Selain sanksi pidana sebagaimana dimaksud pada ayat (1) pelaku dapat dikenai pidana tambahan berupa pemberhentian secara tidak dengan hormat dari jabatannya.

Jelas di setiap Provinsi di Indonesia telah dibentuk Badan Pelayanan Perizinan Terpadu (BP2T) yang tugasnya memberikan kewenangan penerbitan izin pada pengusul. Dalam prakteknya, pada kasus Rawa Tripa di Kabupaten Nagan Raya, Pemerintah Aceh justru menerbitkan izin Hak Guna Usaha (HGU) kepada pihak pengusaha pengusul tanpa merujuk dari perundang-undangan yang berlaku dinegara ini. Komunikasi Kebijakan Pemerintah semakin jelas terlihat sangat tidak berjalan dengan semestinya.

Dalam istilah hukum "Stric liability" dapat dipertanggungjawabkan perbuatan kepada barang siapa, yang telah nyata secara fakta hukum memberikan Izin atas kawasan yang telah dinyatakan dalam Peraturan Pemerintah Nomor 26 Tahun 2008 Tentang Rencana Tata Ruang Nasional yang menyebutkan Kawasan bergambut sebagaimana dimaksud dalam Pasal 52 ayat (1) huruf (b) ditetapkan dengan kriteria ketebalan gambut 3 (tiga) meter atau lebih yang terdapat di hulu sungai atau rawa.selain itu dalam peta pola Ruang Wilayah Nasional lampiran tujuh (VII) berdasarkan Peraturan Pemerintah Nomor 26 Tahun 2008 tersebut menggambarkan pula bahwa hutan gambut yang ada diwilayah tersebut merupakan Kawasan Lindung ; yang mana hal tersebut menimbulkan kerugian bagi lingkungan atas dampak yang akan terjadi akibat kejahatan tersebut, untuk itu beyond reasonable doubt perbuatan pemberian Izin tersebut telah tegas dan tandas oleh karena 
telah secara melawan hukum sebagaimana telah diatur dalam ketentuan Perundangundangan.

\section{Melanggar Konservasi Sumber Daya Alam dan Hayati}

Melirik kasus Rawa Tripa Nagan Raya Aceh yang dikumandangkan oleh Tim Koalisi Penyelamatan Rawa Tripa (TKPRT) Aceh (Kompas.com), Komunikasi Kebijakan Pemerintah terlihat buruk. Ego sektoral antara pemerintah daerah dan Pusat sangat berbeda pemahaman komunikasi kebijakan yang dijalankan. Dalam rilis TKPRT yang dipublis melalui media menujukan kekhawatiran mereka terhadap pelangaran yang dilakukan perusahaan dikawasan Rawa Tripa karena telah mengganggu kawasan dan habitan di Rawa Tripa yang jelas-jelas merupakan Kawasan Ekosistem Leuser, dalam uraiannya dijelaskan:

1. Fauna; Orangutan Sumatera, berbagai jenis primata lainnya juga dapat ditemukan di Rawa Tripa, seperti siamang, wau-wau dan kedih. Sedangkan satwa langka lainnya yang terdapat di kawasan ini antara lain Harimau Sumatera (Panthera tigris sumatraensis), beruang madu (Helarctos malayanus), buaya rawa (Crocodylus porosus), ular python (sanca), serta berbagai jenis burung rawa seperti bangau storm (Ciconia stormi), dan burung belibis (Cairina scutulata).

2. Flora, Vegetasi dan jenis-jenis tumbuhan di Tripa juga diperkirakan memiliki komposisi sangat beragam, sebagaimana rawa gambut lainnya di Sumatera (Laumonier, 1997). Selain nilai keanekaragaman hayati, Rawa Tripa juga memiliki fungsi ekologis sangat penting bagi kehidupan masyarakat sekitarnya.

3. Lahan gambut memiliki peranan hidrologis penting karena secara alami berfungsi sebagai cadangan (reservoir) air dengan kapasitas sangat besar. Jika tidak mengalami gangguan, lahan gambut dapat menyimpan air sebanyak $0,8-0,9 \mathrm{~m} 3 / \mathrm{m} 3$ (Murdiyarso et al, 2004).

Pada Pasal 9 ayat 1 dan 2 Undang-undang Nomor 5 Tahun 1990 tentang Konservasi Sumber Daya Alam Hayati dan Ekosistemnya menyebutkan:

a. Setiap Pemegang hak atas tanah dan hak pengusahaan di perairan dalam wilayah sistem penyangga kehidupan wajib menjaga kelangsungan fungsi perlindungan tersebut.

b. Dalam rangka pelaksanaan perlindungan sistem penyangga kehidupan, pemerintah mengatur serta melakukan tindakan penertiban terhadap terhadap penggunaan dan pengelolaan tanah dan hak pengusahaan di perairan yang terletak dalam wilayah perlindungan sistem penyangga kehidupan sebagaimana dimaksud pada Pasal 8.

\section{Melanggar Agraria}

Dalam Pasal 15 Undang-Undang Nomor 5 Tahun 1960 tentang Peraturan Dasar Pokok-Pokok Agraria menyatakan bahwa memelihara tanah, termasuk menambah kesuburannya serta mencegah kerusakannya adalah kewajiban tiap-tiap orang, badan hukum atau instansi yang mempunyai hubungan hukum dengan tanah itu, dengan memperhatikan pihak yang ekonomis lemah. Dalam penjelasan menyebutkan bahwa "Sudah dijelaskan dalam Penjelasan Umum (II angka 4). Tanah wajib dipelihara dengan baik, yaitu dipelihara menurut cara-cara yang lazim dikerjakan di daerah yang bersangkutan, sesuai dengan petunjuk-petunjuk dari Jawatan-Jawatan yang bersangkutan. 


\section{Melanggar Aturan Perundangan Lainnya}

Selain melanggar Undang-Undang dinegara ini, kebijakan perizinan yang diterbitkan oleh pemerintah juga melanggar secara jelas dibeberapa peraturan pemerintah yang diterbitkan lembaga negara itu sendiri. Adapun beberapa pelanggaran yang dilanggar dapat dilihat dan dijelaskan sebagai berikut (Aristora, 2014);

a. Undang-Undang Nomor 11 Tahun 2006 Tentang Pemerintah Aceh yang telah mengamanatkan Rawa Tripa yang menjadi bagian dari Kawasan Ekosistem Leuser menjadi kawasan yang dilindungi dan pemanfaatannya mengacu pada aturan-aturan yang ditentukan dalam Pasal 9 ayat 2 huruf (a s.d f). Dan Pasal 16 huruf (j), Pasal 143 ayat (3), Pasal 148, Pasal 149, Pasal 150 ayat (1). Pasal 147 yang menyatakan: Pelaksanaan pembangunan di Aceh dan kabupaten/kota dilakukan dengan mengacu pada rencana pembangunan dan tata ruang nasional yang berpedoman pada prinsipprinsip pembangunan berkelanjutan, pelestarian fungsi lingkungan hidup, kemanfaatan, dan keadilan. Dimana pada Pasal 150 ayat (1) dinyatakan bahwa: Pemerintah menugaskan Pemerintah Aceh untuk melakukan pengelolaan kawasan ekosistem Leuser di wilayah Aceh dalam bentuk pelindungan, pengamanan, pelestarian, pemulihan fungsi kawasan dan pemanfaatan secara lestari.

b. Perizinan yang dikeluarkan oleh pemerintah daerah sering tidak mengacu pada peraturan lalinnya, salah satu contonya; Izin Usaha Perkebunan Budidaya kepada PT. Kalista Alam dikawasan Rawa Gambut Tripa belum mengacu kepada Keputusan Menteri Kehutanan Nomor 10 Tahun 2010, tentang Tata Cara Perubahan Peruntukan dan Fungsi Kawasan Hutan serta Peraturan Pemerintah Nomor 60 Tahun 2009 tentang Perubahan Atas Peraturan Pemerintah Nomor 45 Tahun 2004, tentang Perlindungan Hutan.

c. Izin yang keluarkan juga mencederai Intruksi Presiden Nomor 10 Tahun 2011 tentang Penundaan Pemberian Izin Baru dan Penyempurnaan Tata Kelola Hutan Alam Primer dan Lahan Gabut.

d. Peraturan Pemerintah Nomor 27 Tahun 1991 tentang Rawa, Pasal 6 ayat (1) disebutkan bahwa rawa sebagai sumber air merupakan salah satu sumber daya alam yang mempunyai fungsi serbaguna bagi kehidupan dan penghidupan manusia. Kemudian ayat (2) disebutkan rawa sebagaimana dimaksud dalam ayat (1) dilindungi dan dijaga kelestariannya serta ditingkatkan fungsi dan kemanfaatannya. Kemudian Pasal 9 huruf (b) terkait kelestarian rawa dan Pasal 10 tentang Perlindungan Rawa.

e. Peraturan Pemerintah Nomor 26 Tahun 2008 Tentang Rencana Tata Ruang Wilayah Nasional (RTRWN) yang menyebutkan Kawasan bergambut sebagaimana dimaksud dalam Pasal 52 ayat (1) huruf (b) ditetapkan dengan kriteria ketebalan gambut (tiga) meter atau lebih yang terdapat di hulu sungai atau rawa.

f. Keputusan Presiden Nomor 32 Tahun 1990 menyatakan Gambut dengan Kedalaman lebih dari 3 (tiga) meter harus dilindungi.

g. Undang-Undang Nomor 5 Tahun 1994 tentang Konvensi Perserikatan BangsaBangsa mengenai Keanekaragaman Hayati (Lembaran Negara Tahun 1994 Nomor 41, Tambahan Lembaran Negara Nomor 3356).

h. Undang-Undang Nomor 6 Tahun 1994 tentang Ratifikasi Pemerintah terhadap Konvensi Perserikatan Bangsa Bangsa mengenai Perubahan Iklim (Lembaran Negara RI Tahun 1994 Nomor 41, Tambahan Lembaran Negara Nomor 3557).

i. Undang-Undang Nomor 7 Tahun 2004 tentang Sumber Daya Air (Lembaran Negara RI Tahun 2004 Nomor 32, Tambahan Lembaran Negara Nomor 4420). 
j. Undang-Undang Nomor 21 Tahun 2004 tentang Protokol Cartegena tentang Keamanan Hayati atas Konvensi tentang Keanekaragaman Hayati (Lembaran Negara RI Tahun 2004 Nomor 88, Tambahan Lembaran Negara Nomor 4414).

k. Peraturan Pemerintah Nomor 27 Tahun 1991 tentang Rawa (Lembaran Negara RI Tahun 1991 Nomor 35, Tambahan Lembaran Negara Nomor 3445).

1. Peraturan Pemerintah Nomor 27 Tahun 1999 tentang Analisis Mengenai Dampak Lingkungan (Lembaran Negara RI Tahun 1999 Nomor 59, Tambahan Lembaran Negara Nomor 3838).

m. Peraturan Pemerintah Nomor 4 Tahun 2001 tentang Pengendalian Kerusakan dan atau Pencemaran Lingkungan Hidup yang Berkaitan dengan Kebakaran Hutan dan atau Lahan (Lembaran Negara RI Tahun 2001, Tambahan Lembaran Negara Nomor 4076).

n. Peraturan Pemerintah Nomor 15 Tahun 2010 Tentang Penyelenggaraan Penataan Ruang (Lembaran Negara RI Tahun 2010 Nomor 21).

o. SK Menteri Lingkungan Hidup Nomor 5 Tahun 2001 mengenai panduan AMDAL untuk pembangunan dilahan basah: AMDAL harus dilakukan sebelum dilakukan pembangunan di areal lahan gambut.

\section{Komunikasi Kebijakan Pemerintah Dianggap Melahirkan Pelanggaran}

Komunikasi kebijakan pemerintah yang menjadi subtansi dalam pelanggaran dalam komunikasi kebijakan pemerintah dapat dilihat pada Asas-Asas Umum Pemerintahan Yang Baik (AAUPB). Dalam UU No. 28 Tahun 1999 tentang Penyelenggaraan Yang Bersih dan Bebas dari Korupsi, Kolusi dan Nepotisme (KKN), dalam Pasal 3 disebutkan beberapa asas umum penyelenggaraan negara, yaitu sebagai berikut ;

1. Asas Kepastian Hukum, yaitu asas dalam negara hukum yang mengutamakan landasan peraturan perundang-undangan, kepatutan, dan keadilan dalam setiap kebijakan penyelengaraan negara.

2. Asas Tertib Penyelenggaran Negara, yaitu asas yang menjadi landasan keteraturan, keserasian, dan keseimbangan dalam pengendalian penyelenggaran negara.

3. Asas Kepentingan Umum, yaitu asas yang mendahulukan kesejahteraan umumdengan cara yang aspiratif, akomodatif, dan seletif.

4. Asas Keterbukaan, yaitu asas yang membuka diri terhadap hak masyarakat untuk memperoleh informasi yang benar, jujur, dan tidak diskriminatif tentang penyelenggaran negara dengan tetap memperhatikan perlindungan atas hak asasi pribadi, golongan dan rahasia negara.

5. Asas Proposionalitas, yaitu asas yang mengutamakan keseimbangan antara hak dan kewajiban penyelenggaran negara.

6. Asas Profesionalitas, yaitu asas yang mengutamakan keahlian yang berlandaskan kode etik dan ketentuan peraturan perundangan yang berlaku.

7. Asas Akuntabilitas, yaitu asas yang menentukan bahwa setiap kegiatan penyelenggaran negara harus dapat dipertanggungjawabkan kepada masyarakat atau rakyat sebagai pemegang kedaulatan tertinggi negara sesuai dengan ketentuan peraturan perundang-undangan yang berlaku.

Dalam menerima permohonan dari kelompok masyarakat maupun pihak swasta terhadap permohonan pemanfaatan kawasan untuk kegiatan usaha perkebunan dan industri lainnya sebaiknya melihat asas yang bersifat formal berkenaan dengan prosedur yang harus dipenuhi dalam setiap pembuatan keputusan. Pertimbangan terhadap Asas-Asas Umum Pemerintahan yang Baik (AAUPB) akan memberikan dampak terhadap ;

1. Asas Kepastian Hukum (principle of legal security) 
2. Asas Keseimbangan (principle of proposionality)

3. Asas Kesamaan Dalam Pengambilan Keputusan (principle of equality)

4. Asas Bertindak Cermat (principle of carefulness)

5. Asas Motivasi Untuk Setiap Keputusan (principle of motivation)

6. Asas Tidak Mencapuradukan Kewenangan (principle of non misuse of competence)

7. Asas Permainan Yang Layak (principle of fair play)

8. Asas Keadilan dan Kewajaran (principle of reasonable of prohibition of arbittrariness)

9. Asas Kepercayaan dan Menanggapi Penghargan Yang Wajar (principle of meeting raised expectation)

10. Asas Meniadakan Akibat Suatu Keputusan Yang Batal (principle of undoing the concequences of an annualed decision)

11. Asas Perlindungan atas Pandangan atau Cara Hidup Pribadi (principle of protecting the personal may of life)

12. Asas Kebijaksanaan (sapientia)

13. Asas Penyelenggaran Kepentingan Umum (principle of public service)

Penerbitan izin terhadap HGU maupun IUPHHK kepada masyarakat maupun swasta tampa melihat asas AAUPB maka akan menimbulkan tindak pelanggaran bagi pemerintah sendiri. Ada banyak aturan perundang-udangan yang menjadi acuan penerbitan sebuah perizinan yang dirujuk secara cermat, teliti, jujur dan akuntabilitas dalam menetapkan keputusan terbitnya sebuah izin.

Dalam hal ini, aktivitas pembukaan lahan rawa Tripa yang dilakukan oleh keempat perusahaan perkebunan tersebut (PT. Kalista Alam, PT. Cemerlang Abadi, PT. Gelora Sawita Makmur dan PT. Astra Agro Lestari) telah melanggar peraturan perundangundangan sebagai berikut :

1. Dalam Pasal 15 Undang-Undang Nomor 5 tahun 1960 tentang Peraturan Dasar Pokok-Pokok Agraria menyatakan bahwa memelihara tanah, termasuk menambah kesuburannya serta mencegah kerusakannya adalah kewajiban tiap-tiap orang, badan hukum atau instansi yang mempunyai hubungan hukum dengan tanah itu, dengan memperhatikan pihak yang ekonomis lemah. Dalam penjelasan menyebutkan bahwa "Sudah dijelaskan dalam Penjelasan Umum (II angka 4). Tanah wajib dipelihara dengan baik, yaitu dipelihara menurut cara-cara yang lazim dikerjakan di daerah yang bersangkutan, sesuai dengan petunjuk-petunjuk dari Jawatan-Jawatan yang bersangkutan.

2. Pada pasal 9 ayat 1 dan 2 Undang-undang Nomor 5 tahun 1990 tentang Konservasi Sumber Daya Alam Hayati dan Ekosistemnya menyebutkan :Setiap Pemegang hak atas tanah dan hak pengusahaan di perairan dalam wilayah sistem penyangga kehidupan wajib menjaga kelangsungan fungsi perlindungan tersebut.

3. Dalam rangka pelaksanaan perlindungan sistem penyangga kehidupan, pemerintah mengatur serta melakukan tindakan penertiban terhadap terhadap penggunaan dan pengelolaan tanah dan hak pengusahaan di perairan yang terletak dalam wilayah perlindungan sistem penyangga kehidupan sebagaimana dimaksud pada pasal 8 .

4. Pasal 6 Undang-Undang Nomor 23 Tahun 1997 tentang Pengelolaan Lingkungan Hidup, menyatakan; 1) Setiap orang berkewajiban memelihara kelestarian fungsi lingkungan hidup serta mencegah dan menanggulangi pencemaran dan perusakan, 2) Setiap orang yang melakukan usaha dan/atau kegiatan berkewajiban memberikan informasi yang benar dan akurat mengenai pengelolaan lingkungan hidup. 
5. Pasal 9 Undang-undang Nomor 39 tahun 1999 tentang Hak Azasi Manusia menyatakan :

a. Setiap orang berhak untuk hidup, mempertahankan hidup dan meningkatkan taraf kehidupannya.

b. Setiap orang berhak hidup tenteram, aman, damai, bahagia, sejahtera lahir dan batin.

c. Setiap orang berhak atas lingkungan hidup yang baik dan sehat.

6. Kemudian pada Pasal 6 undang-undang Nomor 39 tahun 1999 disebutkan bahwa :

a. Dalam rangka penegakan hak asasi manusia, perbedaan dan kebutuhan dalam masyarakat hukum adat harus diperhatikan dan dilindungi oleh hukum, masyarakat, dan Pemerintah.

b. Identitas budaya masyarakat hukum adat, termasuk hak atas tanah ulayat dilindungi, selaras dengan perkembangan zaman.

7. Pasal 25 Undang-Undang No. 18 tahun 2004 tentang Perkebunan menyebutkan bahwa :

1) Setiap pelaku usaha perkebunan wajib memelihara kelestarian fungsi lingkungan hidup dan mencegah kerusakannya.

2) Untuk mencegah kerusakan fungsi lingkungan hidup sebagaimana dimaksud pada ayat (1), sebelum memperoleh izin usaha perkebunan perusahaan perkebunan wajib :

a) Membuat analisis mengenai dampak lingkungan hidup atau upaya pengelolaan lingkungan hidup dan upaya pemantauan lingkungan hidup.

b) Membuat pernyataan kesanggupan untuk menyediakan sarana, prasarana dan sistem tanggap darurat yang memadai untuk menanggulangi terjadinya kebakaran dalam pembukaan dan atau pengolahan lahan.

c) Memiliki analisis dan manajemen risiko yang menggunakan hasil rekayasa genetik.

8. Untuk memelihara kelestarian fungsi lingkungan hidup dan mencegah dan menanggulangi kerusakannya sebagaimana dimaksud pada ayat (1), setelah memperoleh izin usaha perkebunan, perusahaan perkebunan wajib menerapkan analisis mengenai dampak lingkungan hidup atau upaya pengelolaan lingkungan hidup dan upaya pemantauan lingkungan hidup dan atau analisis dan manajemen risiko lingkungan hidup serta memantau penerapannya.

9. Setiap perusahaan perkebunan yang tidak memenuhi persyaratan sebagaimana dimaksud pada ayat (2) ditolak permohonan Izin usahanya.

10. Setiap perusahaan perkebunan yang telah memperoleh izin usaha perkebunan tetapi tidak menerapkan analisis mengenai dampak lingkungan hidup atau upaya pengelolaan lingkungan hidup dan upaya pengelolaan lingkungan hidup dan upaya pengelolaan lingkungan hidup dan upaya pemantauan lingkungan sebagaimana dimaksud pada ayat (3) dicabut izinnya.

11. Pasal 26 disebutkan "bahwa setiap pelaku usaha perkebunan dilarang membuka dan atau mengolah lahan dengan cara pembakaran yang berakibat terjadinya pencemaran dan kerusakan lingkungan hidup. 
12. Pada pasal 12 ayat 2 huruf b Undang-undang Nomor 11 tahun 2005 tentang Pengesahan International convention on Economic, Social and Cultural Rights (kovenan internasional tentang hak-hak ekonomi, sosial dan budaya) menyebutkan bahwa langkah-langkah yang akan diambil oleh Negara Pihak pada Kovenan ini guna mencapai perwujudan hak ini sepenuhnya, harus meliputi hal-hal yang diperlukan untuk mengupayakan perbaikan semua aspek kesehatan lingkungan dan industri;

13. Selanjutnya, dalam Pasal 1 angka 21 Undang-Undang Nomor 26 Tahun 2007 tentang Penataan Ruang disebutkan bahwa kawasan lindung adalah wilayah yang ditetapkan dengan fungsi utama melindungi kelestarian lingkungan hidup yang mencakup sumber daya alam dan sumber daya buatan.

14. Pasal 5 angka 2 Undang-Undang Nomor 26 tahun 2007 tentang Penataan Ruang menyebutkan penataan ruang berdasarkan fungsi utama kawasan terdiri atas kawasan lindung dan kawasan budidaya. Yang dimaksud dengan kawasan lindung dalam penjelasannya adalah :

a. kawasan yang memberi perlindungan terhadap kawasan bawahannya, antara lain kawasan hutan lindung, kawasan bergambut, dan kawasan resapan air;

b. kawasan perlindungan setempat antara lain sempadan pantai, sempadan sungai, kawasan sekitar danau/waduk dan kawasan sekitar mata air;

c. kawasan suaka alam dan budaya antara lain kawasan suaka alam, kawasan suaka alam laut, dan perairan lainnya, kawasan pantai berhutan bakau, taman nasional, taman hutan raya, taman wisata alam, cagar alam, suaka margasatwa, serta kawasan cagar budaya dan ilmu pengetahuan;

d. kawasan bencana alam antara lain kawasan rawan letusan gunung berapi, kawasan rawan gempa bumi, kawasan rawan tanah longsor, kawasan rawan gelombang pasang dan kawasan rawan banjir, dan;

e. kawasan lindung lainnya, misalnya taman buru, cagar biosfer, kawasan perlindungan plasma nutfah, kawasan pengungsian satwa dan terumbu karang.

15. Pasal 61 Undang-undang Nomor 26 tahun 2007 tentang Penataan Ruang, menyatakan bahwa dalam pemanfaatan ruang setiap orang wajib :

1) menaati rencana tata ruang yang telah ditetapkan

2) memanfaatkan ruang sesuai dengan izin pemanfaatan ruang dari pejabat yang berwenang

3) mematuhi ketentuan yang ditetapkan dalam persyaratan izin pemanfaatan ruang,

4) memberikan akses terhadap kawasan yang oleh ketentuan peraturan perundang-undangan dinyatakan sebagai milik umum.

16. Pasal 9 Peraturan Pemerintah Nomor 27 tahun 1991 tentang Rawa menyebutkan bahwa konservasi rawa ditujukan untuk mempertahankan dan melindungi ekosistem rawa sebagai sumber air, serta meningkatkan fungsi dan manfaatnya dengan memperhatikan :

a. Kemampuan meningkatkan rawa sebagai ekosistem sumber air; 

b. Pelestarian rawa;
c. Kemampuan meningkatkan perekonomian masyarakat;
d. Kelestarian lingkungan hidup.

17. Pada pasal 15 menyebutkan :

a. Dalam rangka pelaksanaan perlindungan di wilayah konservasi rawa setiap orang dilarang untuk :

1) Merusak ekosistem air yang berada di wilayah konservasi rawa;kehidupan dan sumber

2) Membuang benda dan/atau bahan padat maupun cair yang berupa limbah ke dalam wilayah konservasi rawa;

b. Setiap pemegang hak atas tanah di dalam wilayah konservasi rawa wajib menjaga kelangsungan fungsi wilayah tersebut.

18. Berdasarkan Pasal 12 ayat 1 poin e, Peraturan Pemerintah no. 40 tahun 1996 tentang Hak Guna Usaha, Hak Guna Bangunan, Hak Pakai atas tanah yang menyebutkan tentang kewajiban pemegang Hak Guna Usaha salah satunya adalah bahwa pemegang Hak Guna Usaha harus mencegah kerusakan sumber daya alam dan menjaga kelestarian kemampuan lingkungan hidup sesuai dengan peraturan perundang-undangan yang berlaku.

19. Pasal 14 ayat 2 Peraturan Pemerintah no. 40 tahun 1996 disebutkan bahwa Penguasaan dan penggunaan sumber daya alam lainnya diatas tanah yang diberikan dengan Hak Guna Usaha untuk pemegang Hak Guna Usaha sebagaimana dimaksud dalam ayat (1) dengan mengingat ketentuan peraturan perundang-undangan yang berlaku dan kepentingan masyarakat.

20. Peraturan pemerintah No 26-2008 tentang RTRWN menetapkan kawasan Ekosistem Leuser sebagai kawasan strategis nasional untuk pelestarian lingkungan hidup. Rawa Tripa yang merupakan rawa gambut merupakan bagian dari KEL. Dalam pasal 52 huruf $\mathrm{b}$ dinyatakan bahwa kawasan bergambut merupakan kawasan lindung yang memberikan perlindungan terhadap kawasan bawahannya.

21. Pada pasal 9 ayat 2 Peraturan Pemerintah tersebut memuat arahan strategi untuk pelestarian dan peningkatan fungsi dan daya dukung lingkungan hidup yang meliputi

a. Menetapkan kawasan strategis nasional berfungsi lindung;

b. Mencegah pemanfaatan ruang dikawasan strategis nasional yang berpotensi mengurangi fungsi lindung kawasan;

c. Membatasi pemanfaatan ruang di sekitar kawasan strategis nasional yang berpotensi mengurangi fungsi lindung kawasan;

d. Membatasi pengembangan prasarana dan sarana di dalam dan di sekitar kawasan strategis nasional yang dapat memicu perkembangan kegiatan budidaya;

e. Mengembangkan kegiatan budidaya tidak terbangun di sekitar kawasan strategis nasional yang berfungsi sebagai zona penyangga yang memisahkan kawasan lindung dengan kawasan budidaya terbangun; dan 
f. Merehabilitasi fungsi lindung kawasan yang menurun akibat dampak pemanfaatan ruang yang berkembang di dalam dan di selitar kawasan strategis nasional.

22. Pasal 1 angka 1 Keputusan Presiden Nomor 32 tahun 1990 Tentang Pengelolaan Lingkungan menyebutkan bahwa kawasan Lindung adalah kawasan yang ditetapkan dengan fungsi utama melindungi kelestarian lingkungan hidup yang melindungi yang mencakup sumber alam, sumber daya buatan dan nilai sejarah serta budaya bangsa guna kepentingan pembangunan yang berkelanjutan.

23. Pasal 1 angka 4 Keputusan Presiden Nomor 32 tahun 1990 Tentang Pengelolaan Lingkungan menyebutkan bahwa kawasan bergambut adalah kawasan yang unsur pembentuk tanahnya sebagian besar berupa sisa-sisa bahan organik yang tertimbun dalam waktu yang lama.

24. Pasal 2 ayat 1 dan 2 Keputusan Presiden Nomor 32 tahun 1990 Tentang Pengelolaan Lingkungan menyebutkan :

a. Pengelolaan kawasan lindung bertujuan untuk mencegah timbulnya kerusakan fungsi lingkungan hidup.

b. Sasaran pengelolaan kawasan lindung adalah :

1) Meningkatkan fungsi lindung terhadap tanah, air, iklim, tumbuhan dan satwa serta nilai sejarah dan budaya bangsa.

2) Mempertahankan keanekaragaman tumbuhan, satwa, tipe ekosistem dan keunikan alam.

25. Pasal 3 angka 1 Keputusan Presiden Nomor 32 tahun 1990 Tentang Pengelolaan Lingkungan yang menyebutkan salahsatu kawasan lindung yang dimaksud dalam pasal 1 adalah kawasan yang memberikan perlindungan terhadap kawasan bawahannya. Pasal 4 Keputusan Presiden Nomor 32 tahun 1990 Tentang Pengelolaan Lingkungan yang menyebutkan kawasan yang memberikan perlindungan kawasan bawahannya sebagaimana yang dimaksud dalam pasal 3 terdiri dari:
a. Kawasan hutan lindung
b. Kawasan bergambut
c. Kawasan Resapan air

26. Pasal 9 Keputusan Presiden Nomor 32 tahun 1990 Tentang Pengelolaan Lingkungan menyebutkan perlindungan terhadap kawasan bergambut dimaksudkan untuk mengendalikan hidrologi wilayah yang berfungsi sebagai penambat air dan pencegah banjir serta melindungi ekosistem yang khas di kawasan yang bersangkutan. Pasal 10 Keputusan Presiden Nomor 32 tahun 1990 Tentang Pengelolaan Lingkungan menyebutkan kriteria kawasan bergambut adalah tanah bergambut dengan ketebalan 3 meter atau lebih yang terdapat dibagian hulu sungai dan rawa.

\section{KESIMPULAN}

Pelanggaran komunikasi kebijakan Pemerintah dapat dimasukan dalam ranah pelanggaran Perdata dan Pidana. Untuk menciptakan pemerintah yang bersih sesuai dengan Undang-Undang Nomor 28 Tahun 1999 Tentang Penyelenggaraan negara yang bersih dan bebas dari Korupsi, Kolusi dan Nepotisme, akan sangat jauh dari harapan bila proses 
komunikasi yang jelas belum terbangun serta ego sektoral masih menjadi alasan yang tersirat dari setiap kebijakan pemerintah.

Kondisi saat ini, baik dari pemerintah pusat dan daerah, proses komunikasi pemerintahan seakan tersendat. Rakyat seakan sudah hilang kepercayaan terhadap pemerintah. Begitupun pemerintah yang seakan tidak tanggap terhadap segala suara rakyat. Masalah ini bisa kita lihat dalam contoh kasus pembuatan kebijakan publik. Terlalu banyak kebijakan pemerintah yang memang tidak pro rakyat, bahkan tidak sesuai dengan keinginan rakyat. Padahal dalam hal pencapaian tujuan negara, terdapat tujuan rakyat tiap individu.

Para anggota dewan dan pemerintahan kita seolah hanya bisa mengobral janji kepada rakyat. Memberi harapan begitu besar saat kampanye, tapi toh kemudian ketika mereka telah mendapat jabatan, janji tinggal janji, kesengsaraan rakyat semakin menjadi. Inilah kemudian uyang menjadi sorotan semua pihak, termasuk di dalamnya para akademisi, pakar politik, pemerintaha gagal berkomunikasi dengan baik dengan rakyat.

Artinya komunikasi pemerintahan tidak berjalan dengan baik. Kebijakan-kebijakan yang dibuat tidak sesuai dengan keinginan rakyat banyak. Kebijakan publik meliputi semua kebijakan yang berasal dari pemerintah, seperti kebijakan ekonomi, transportasi, komunikasi, pertahanan dan keamanan, serta fasilitas-fasilitas umum lainnya. Menurut Dye, kebijakan publik didefinisikan sebagai "whatever government choose to do or not to do".

Sedangkan menurut Young dan Quinn salah satu konsep kunci dari kebijakan publik adalah sebuah reaksi terhadap kebutuhan dan masalah dunia nyata. Kebijakan publik berupaya merespon masalah atau kebutuhan konkrit yang berkembang di masyarakat. Lebih lanjut dijelaskan bahwa kebijakan publik merupakan seperangkat tindakan yang berorientasi pada tujuan. Kebijakan publik biasanya bukanlah sebuah keputusan tunggal, melainkan terdiri dari beberapa pilihan tindakan atau strategi yang dibuat untuk mencapai tujuan tertentu demi kepentingan orang banyak.

Fenomena diatas, dalam memberi efek jera dan komunikasi kebijakan ini dapat berjalan dengan baik maka perlu kita ingatkan bahwa selaku Penyelenggara Negara secara sengaja melakukan tindakan melawan hukum sehingga dapat di jerat dengan UndangUndang Nomor 31 Tahun 1999 tentang Pemberantasan Tindak Pidana Korupsi, Pasal 2 ayat (1), Jo. Undang-Undang Nomor 20 Tahun 2001, tentang Perubahan Atas UndangUndang Nomor 31 Tahun 1999 tentang Pemberantasan Tindak Pidana Korupsi, Pasal 12, huruf (h), Pegawai Negeri atau Penyelenggara Negara yang pada waktu menjalankan tugas, telah mengunankan Tanah Negara yang diatasnya terdapat hak pakai, seolah-olah sesuai dengan peraturan perundang-undangan, telah merugikan orang yang berhak, padahal diketahui peraturan tersebut bertentangan dengan peraturan perundangan.

Kebakaran hutan dan lahan di Negara ini, bila ditenggarai dengan unsur kesengajaan atas penerbitan sebuah izin tanpa membangun sebuah garis komando komunikasi yang jelas berdasarkan hirarki hukum pada kawasan HGU dan Perkebunan yang tidak sesuai aturan dapat ditindak secara tegas dengan Tindak Pidana Korupsi. Sementara pelaku utama pembakar lahan dapat dijerat dengan Pasal-Pasal berlapis agar memberi efek jera kepada pengusaha lainnya untuk menjaga kawasan yang dibebankan izin pemanfaatan kepada mereka tetap dijaga sesuai dengan aturan yang berlaku dinegara ini. 


\section{DAFTAR PUSTAKA}

Bernard L. Tanya, dkk, 2010. Teori Hukum Strategi Tertib Manusia Lintas Ruang dan Generasi. Genta Publishing, Yogyakarta.

Dr. Siswanto Sunarso, S.H, M.H . 2005. Hukum Pidana Lingkungan hidup dan strategi penyelesaian sengketa. Penerbit Rineka Cipta.

Ridwan HR. 2013. Hukum Administrasi Negara. Rajawali Press.

Irsadi Aristora. 2014. Saat Asap Merenggut Hak Asazi Manusia. Kompasiana.

2014. Water Management For Forest Plantation In Tropical Peatlands Hasil Riset Tim MRV di PT. RAPP Terbantahkan Akibat Karhutla Riau. Kompasiana. 2014. Rawa Tripa Dalam Catatan Advokasi Bersama. Aceh.

Prof. Dr. Jimly Asshiddiqie., SH dan M. Ali Safa'at,. SH,. MH. 2006. Teori Hans Kelsen Tentang Hukum, Sekretariat Jendral \& Kepaniteraan Mahkamah Konstitusi RI, Jakarta.

Rafiansa Zawani. 2014. Pengaruh Komunikasi Dalam Sosialisasi Kebijakan Pemerintah. Mahasiswa FISIP-UI.

www.nasional.kompas.com/read/2012/11/27/1555106/gubernur.aceh.didesak.awasi.lahan .sengketa. di.rawa.tripa

www.mongabay.co.id/2012/05/14/koalisi-desak-menhut-tuntaskan-kasus-rawa-tripa/ 